HATTA SHŪZŌ AND PURE ANARCHISM IN INTERWAR JAPAN 
Also by John Crump

NON-MARKET SOCIALISM IN THE NINETEENTH AND

TWENTIETH CENTURIES (edited with Maximilien Rubel) STATE CAPITALISM: The Wages System under New

Management (co-authored with Adam Buick)

THE ORIGINS OF SOCIALIST THOUGHT IN JAPAN 


\section{Hatta Shūzō and \\ Pure Anarchism in \\ Interwar Japan}

John Crump

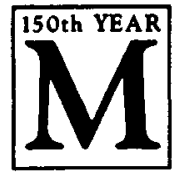

St. Martin's Press 


\section{John Crump 1993}

Softcover reprint of the hardcover 1st edition 1993

All rights reserved. No reproduction, copy or transmission of this publication may be made without written permission.

No paragraph of this publication may be reproduced, copied or transmitted save with written permission or in accordance with the provisions of the Copyright, Designs and Patents Act 1988, or under the terms of any licence permitting limited copying issued by the Copyright Licensing Agency, 90 Tottenham Court Road, London WIP 9HE.

Any person who does any unauthorised act in relation to this publication may be liable to criminal prosecution and civil claims for damages.

First published in Great Britain 1993 by

THE MACMILLAN PRESS LTD

Houndmills, Basingstoke, Hampshire RG21 2XS

and London

Companies and representatives

throughout the world

A catalogue record for this book is available

from the British Library.

ISBN 978-1-349-23040-2

DOI 10.1007/978-1-349-23038-9

ISBN 978-1-349-23038-9 (eBook)

First published in the United States of America 1993 by

Scholarly and Reference Division,

ST. MARTIN'S PRESS, INC.,

175 Fifth Avenue,

New York, N.Y. 10010

ISBN 978-0-312-10631-7

Library of Congress Cataloging-in-Publication Data

Crump, John, 1944

Hatta Shūzō and pure anarchism in interwar Japan / John Crump.

p. $\mathrm{cm}$.

Includes bibliographical references and index.

ISBN 978-0-312-10631-7

1. Anarchism-Japan-History. 2. Hatta, Shüzö, 1886-1934.

I. Title.

HX947.C78 1993

$335^{\prime} .83^{\prime} 0952-\mathrm{dc} 20$ 
This book is dedicated to Derek and Marjorie Crump, who taught me that no things are more important than mutual love, social justice, and decency in human relations 


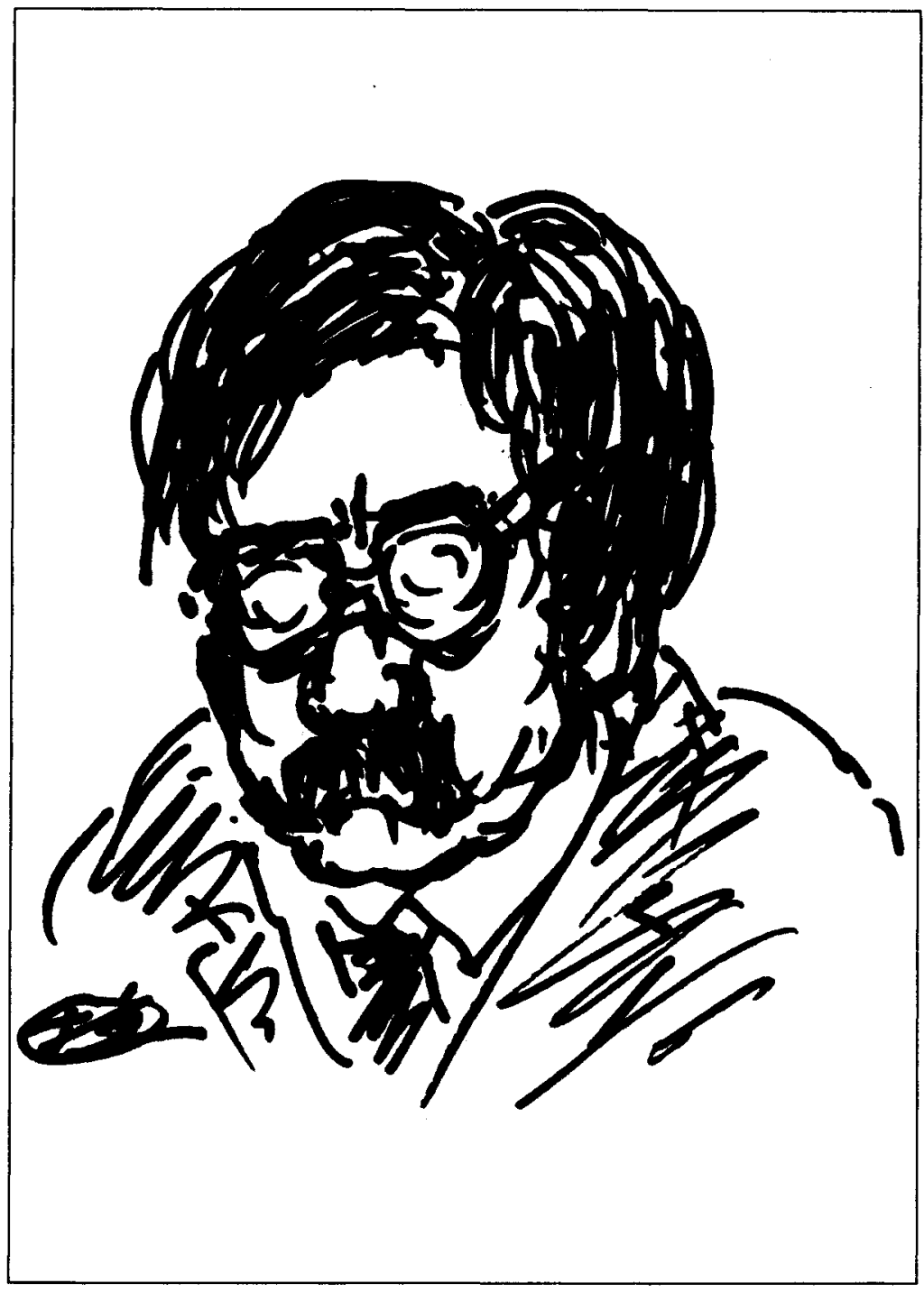

Sketch of Hatta Shūzō by Mochizuki Kei 


\section{Contents}

Acknowledgements

Introduction: the Importance of Pure Anarchism

ix

Map of Principal Japanese Islands

xi

xix

1 Anarchist Communism 1

2 Japanese Anarchism to 1923

Kōtoku Shūsui and Anarchism 21

High Treason and its aftermath $\quad 30$

The End of the 'Winter Period' 35

3 Hatta Shūzō: Christian Pastor to Anarchist Militant $\mathbf{4 5}$ Origins and Education $\quad 46$

Provincial Clergyman $\quad 50$

Anarchist Propagandist $\quad 56$

Theoretician of Pure Anarchism 60

Decline and Death $\quad 64$

4 Organisational Confrontation: Pure Anarchists versus Syndicalists 1926-31

Kokuren $\quad 69$

Zenkoku Jiren $\quad 75$

Zenkoku Jiren's Second Conference 83

Kokuren and Zenkoku Jiren after the split $\quad 87$

The Anarchist Syndicalists $\quad 95$

5 Critique of the Old World 101

Syndicalism 101

The Division of Labour 104

The Class Struggle $\quad 111$

Physiocracy (Jünōshugi) 118

Science $\quad 123$

$\begin{array}{ll}\text { Marxism } & 128\end{array}$ 
6 Hope for a New World 137

Social Physiology 138

Decentralisation $\quad 141$

Abolishing the Division of Labour and

Exploitation

146

Taking Consumption as the Basis $\quad 151$

A World to Win 154

7 Repression, 1931-6 159

Zenkoku Jiren after $1931 \quad 160$

Nōson Seinen Sha (Farming Villages

Youth Association) 172

Nihon Museifu Kyōsantō (Anarchist Communist

Party of Japan)

8 Pure Anarchism: an Assessment 189

Notes $\quad 205$

Select Bibliography $\quad 217$

Index $\quad 221$ 


\section{Acknowledgements}

Writing this book has involved a great deal of painstaking work and most of my 'spare time' during the past five years. What has made it worthwhile, in addition to the fascination of the subject, are the many fine people who have helped and encouraged me during those years. The main fieldwork for the book was carried out during 1990, when a fellowship from the Japan Foundation enabled me to spend three months at Keiō University in Tōkyō. I chose to be based at Keiō because the foremost authority on Japanese anarchism, Komatsu Ryūji, is a professor there. His encouragement, interest and unparalleled knowledge of the subject enriched my time in Japan enormously. I also incurred considerable debts to Ōshima Eizaburō and Mihara Yōko. Ōshima-san has spent a small fortune in financing Kokushoku Sensensha's (the Black Battlefront Company) republication of numerous, otherwise unobtainable, anarchist texts. As one of the few surviving anarchists of the interwar era, he also provides an inspiring link with the past. I gratefully acknowledge the fact that much of the research material I obtained from him was priceless in both senses of the word. Discussions with Mihara-san always enlivened my visits to Kyōto and study of her informative writings on anarchism in interwar Japan provided me with much food for thought. I am particularly grateful to her for efficiently answering several requests for factual clarification after I returned to England. Another person whose kindness I wish to acknowledge is Mochizuki Akiyoshi, who permitted me to include in this book a sketch of Hatta Shüzō which was drawn by his father, the famous anarchist artist Mochizuki Kei.

In Europe my thanks are mainly due to friends and comrades whose interest in my research encouraged me to believe, even when the going was tough, that the project was worthwhile. I cannot mention them all by name, but it would be churlish to omit the following four. Adam Buick in London and Peter Nicholson in York were kind enough to com- 
ment on early chapters of my manuscript. I am grateful for their useful and informed criticisms. Alain Pengam in Paris read the entire manuscript and thus I benefited from his detailed knowledge of anarchist communism. Mark Shipway in Leeds also read the entire manuscript and his many helpful comments were unfailingly meticulous in their attention to detail and their communist content. I am pleased to be able to use this opportunity to pay tribute to Mark as an exemplary friend and comrade.

Last, but not least, come the three women in my life. With good humour, Emily Midorikawa Crump and Erica Midorikawa Crump put up with their father's strange enthusiasms for visiting obscure bookshops, for paying respect at the graves of fallen revolutionaries, and for interminable discussions on the minutiae of anarchist communism. Their only resistance as they traipsed behind me across the length and breadth of a very different Japan from that which features in the glossy brochures was to rename Hatta Shūzo 'Hatta Shoesore'. Midorikawa Taeko helped me in more ways than she knows or I can record. Her just being there was no less important than her obvious role of checking my translations of the pure anarchists' Japanese on the many occasions when they expressed themselves in language which was even more convoluted, polemical or jargon-ridden than usual. The best compliment I can pay to these women in my life is that, if ever we do achieve a society which is both anarchist and communist, it will be inhabited by people like them.

JoHN CRUMP

\section{Author's Note}

Japanese names are given in the customary East Asian form, i.e. family name (e.g. Hatta) followed by personal name (e.g. Shūzō). Long vowels in Japanese words are indicated by macrons (e.g. ō). 


\section{Introduction: the Importance of Pure Anarchism}

'Pure anarchism' was the dominant current within Japanese anarchism during the interwar years. Its adherents were anarchist communists who wished to rid anarchism of the 'impurity' of syndicalism. It might well be asked: why write a book on these pure anarchists? After all, did they not ultimately fail in their attempt to establish an anarchist communist society and are they not largely forgotten today even within Japan? Besides, was it not Spain where anarchism's life-and-death struggle was fought in the 1930s? Why, then, should we in Europe pay much attention to what happened during roughly the same period in an East Asian country, far removed from the drama in Spain?

In reply, I can give at least three reasons why a study of Japanese pure anarchism is worthwhile. First, the image of the Japanese (including Japanese working men and women) which has prevailed in the West during recent decades has been of an overwhelmingly conformist and docile people. The oft-repeated epithet 'economic animals' has been used to describe the apparent character of the Japanese during much of the postwar period and has conveyed their seeming indifference to political principles or ethical questions. At an early stage of my research into pure anarchism I read a paper on 'The Communist Idea in Japan' at a seminar in Oxford, where I was criticised because I had supposedly overlooked the 'fact' that the Japanese are the most unrevolutionary, order-loving and conformist people in the world. Of course, this widely held image derives from attributing to all Japanese in all eras certain characteristics which, even if present today (and it is arguable that they are nowhere near as universal as is often claimed), are of very short historical duration. Not only does this image conflict with the percep- 
tion of the Japanese as a revolutionary people, which was widespread throughout East Asia in the years following the upheaval of 1868 , but it also clashes with the supposedly unJapanese concern for political principles and ideological clarity which was demonstrated by the pure anarchists of the interwar years. Hence one reason for writing a book on the pure anarchists is that I think it is instructive to draw the attention of Western readers to those 'other Japanese', those whose very existence (irrespective of their concrete achievement) modifies the negative image projected by their depressingly conformist countrymen and countrywomen.

A second reason for my interest in the pure anarchists is that they represent an authentically Japanese expression of the universal principles of communism. By communism I mean, of course, not the system of bureaucratic power, party domination, and state manipulation of the economy found in countries such as (until recently) Russia and China, but the project to reorganise society so as to achieve a community of social equals who would control the means of production communally, cooperatively organise production for the direct satisfaction of needs, and consume by taking freely from the commonly held wealth of society. Such a vision of social reorganisation got its first fully worked-out presentation in Japanese when Petr Kropotkin's (1842-1921) The Conquest of Bread was translated in 1909. Although The Conquest of Bread struck a responsive chord among many radical Japanese of that era, it remained very much a Japanese translation of an essentially European work. The very title The Conquest of Bread (as opposed to The Conquest of Rice) indicates the (for many Japanese) exotically European flavour of Kropotkin's passionate arguments for communism. Kropotkin remained the dominant influence on the pure anarchists during the interwar years and this was reinforced when his Collected Works were published in Japanese from 1928. Nevertheless, by that period communism had been fully assimilated by its Japanese exponents, so that by then the pure anarchists were able to relate it thoroughly to Japanese society and present it to a Japanese audience in an authentically Japanese form. Thus, when the pure anarchists wrote texts of 
their own to popularise communism, the commune which they, like anarchist communists everywhere, advocated as the unit of communist society had ceased to be a European transplant from Kropotkin's texts and was clearly a Japanese farming village, transformed by an anarchist revolution no doubt, but none the less Japanese for that. Likewise, those who were expected to bring about this social transformation were not cosmopolitan revolutionaries expressing European concepts in katakanaesque Japanese, but flesh and blood products of Japanese society, such as the tenant farmers.

Several years ago Maximilien Rubel and I edited a volume of essays under the title Non-Market Socialism in the Nineteenth and Twentieth Centuries.' 'Non-market socialism' was a synonym for what I have referred to here as 'communism'. Although in that earlier book we chose not to use the word 'communism' because of our concern that it might be misinterpreted as having a connection with the political systems formerly or actually found in Russia, China and elsewhere, there is no alternative to employing the term here, since 'anarchist communism' was the declared aim of the pure anarchists. Our theme in Non-Market Socialism in the Nineteenth and Twentieth Centuries was that, although a communist society has so far never been achieved anywhere, communism has nevertheless had a constant, if unsteady, existence during the nineteenth and twentieth centuries as a challenge to the ideology of capitalism. For as long as there has been industrial capitalism, groups of working men and women have reacted to its existence, and to the indignities and irrationalities which inevitably accompany it, by formulating a communist alternative. The book argued that neither social democracy nor bolshevism represented communist challenges to capitalism, since both were variations on the capitalist theme, in that they left intact the principal constituent elements of capitalism (the wages system, commodity production, state power and so on). The real challenge to capitalism has come from quarters other than social democracy or bolshevism, and the currents we examined as different versions of this communist challenge in the various chapters of our book were the following:- 
1 Anarchist communism, represented from approximately 1880 onwards by a string of thinkers and activists, such as Kropotkin and Alexander Berkman (1870-1936).

2 The impossibilism of currents such as the Socialist Party of Great Britain, which was founded in 1904 in the course of the split between 'possibilists' and 'impossibilists' in the ranks of the Social Democratic Federation in Britain.

3 The council communism associated with the German Revolution of 1918 and its aftermath, which was articulated by theoreticians such as Anton Pannekoek (1873-1960), Otto Rühle (1874-1943) and Paul Mattick (1904-81).

4 Bordigism, which takes its name from Amadeo Bordiga (1889-1970), the first leader of the Communist Party of Italy, before the leadership of that party passed in 1924 to others more acceptable to the Comintern, such as Antonio Gramsci (1891-1937).

5 The situationism of the Situationist International, whose activity spanned the period 1957 to 1972 and was one of the streams feeding the upheaval in Paris in May 1968.

Considered in isolation, it is tempting to dismiss any one of these five currents as too weak to be of much significance. Taken together, however, they represent a sustained critique of capitalism and a consistently posed, communist alternative to it. Naturally, there have been differences between these currents, which have kept them divided and over which they have argued (particularly with regard to the question of means), but each in its own way has effectively kept alive the goal of a communist society and has thus prevented capitalism from enjoying unchallenged ideological supremacy. What gives these currents added significance as a collective phenomenon is that they have emerged largely independently of one another at different historical junctures and in different geographical locations. Bordigism is as recognisably the product of Italian influences and circumstances as impossibilism 
owes much to its Anglo-Saxon origins. The repeated emergence of these organisationally separate and culturally distinct formulations of what still remains essentially the same communist alternative to capitalism suggests that it is in the nature of capitalism, wherever it exists, to evoke a communist response which does not vary in its fundamentals. From the standpoint of the late twentieth century, it may look as though capitalism rules the world untroubled and has successfully countered all attempts to replace it by communism. Yet, as the existence of these communist currents demonstrates, despite its apparatus of ideological domination, capitalism has proved unable to eradicate an alternative communist vision of how society could be organised. As long as varieties of this communist alternative remain to haunt capitalism, its supremacy is less than total and the possibility of achieving communism cannot be discounted.

It is with these considerations in mind that I have approached the study of the Japanese pure anarchists. Since capitalism is a world phenomenon, it would be strange indeed if communist ideological challenges to capitalism were all of European origin, like the five currents mentioned above. Obviously, of the European communist currents which I have identified, Japanese pure anarchism had most in common with European anarchist communism. Nevertheless, as I indicated earlier, the pure anarchists did not simply repeat parrot-fashion lessons learnt by rote from the European anarchist communists. The ability of the pure anarchists to take account of the way in which capitalism had developed in Japan, and to respond creatively to its special features by offering an alternative which was no less communist for being rooted in Japanese conditions, is further confirmation of the argument that capitalism invariably evokes a communist response from within the ranks of those whom it oppresses and exploits. Hence, despite Japanese pure anarchism's lack of concrete success, its very existence can be regarded as significant when it is set within the international context outlined above. Particularly if one's knowledge and experience of communism hitherto have conspired to give it the appearance of a predominantly European ideological 
construct, it can be more than a little exciting to recognise the pure anarchists as the Japanese equivalent of the European currents to which I have alluded.

A third reason for writing a book on the pure anarchists is the sophisticated theoretical level which the best among them were able to achieve. Writing from a European perspective in his chapter in Non-Market Socialism in the Nineteenth and Twentieth Centuries, Alain Pengam claimed that after Kropotkin's death in 1921 the theory of anarchist communism survived for a while, 'but was consigned to isolation by the unfolding counter-revolution from the 1920s onwards'.

Unlike the Italian Left [Bordigists] and the German-Dutch council communists (the latter above all, with their criticism of the whole workers' movement and their analysis of the general tendency for a unification of labour, capital and the state), the partisans of anarcho-communism did not really try to discover the causes of this counterrevolution; nor did they perceive its extent. As a result, their contributions amounted to little more than a formal defence of principles, without any critical depth. Moreover, these contributions ceased very rapidly. Sebastien Faure's Mon Communisme appeared in 1921, Luigi Galleani's The End of Anarchism? in 1925 and Alexander Berkman's What Is Communist Anarchism? (better known in its abridged form as the $A B C$ of Anarchism) in 1929.'

Even with regard to Spanish anarchism, Pengam was sceptical whether the collectivisations in Spain from 1936 contained any anarchist communist potential, since he regarded Spanish 'libertarian communism' of the 1930 s as an 'empty phrase'. ${ }^{3}$

The contrast between the withering of anarchist communist theory in Europe after the First World War and its flowering in Japan during the interwar years is striking. As will be demonstrated in Chapter 1, in Europe after 1918 anarchist communists were largely content to echo Kropotkin's writings and even tolerated a dilution of theoretical clarity, with the result that eventually anarchist communism ceased to have a coherent identity of its own and was incorporated into 
the wishy-washy cocktail of nondescript 'anarchism'. By way of contrast, in interwar Japan the confrontation between anarchist syndicalists and their pure anarchist opponents forced the latter to define ever more clearly the theoretical bases of their activity. As a result, the interwar years were a period of intense theoretical innovation in Japan and, in contrast to what happened in Europe, anarchist communist theory did not stagnate at the points at which Kropotkin had left it or, worse still, even regress. There is a tendency among Japanese commentators to regret the confrontation that occurred between anarchist syndicalists and pure anarchists, and to regard it as the suicide of a movement already beleaguered by the twin enemies of capitalism and bolshevism. Yet, without such intense polemics between anarchist syndicalists and pure anarchists, anarchist communism would probably have withered on the bough in Japan as in Europe, so that there would be no particular reason today for studying a movement which displayed the same fading qualities as its contemporaries in Europe.

Among the theoreticians of pure anarchism none was more innovative or determined to rid anarchist theory of extraneous elements, derived from syndicalism or elsewhere, than Hatta Shūzō (1886-1934). Even in Japan, Hatta is largely forgotten these days outside of anarchist circles. I spent several months in Japan in 1990, engaged in research for this book, and I was struck by the fact that mention of my research theme prompted most scholars with whom I came in contact to dive for the biographical dictionary on their shelves to discover who on earth was Hatta Shūzō. Needless to say, in the West the situation is bleaker still and Hatta is totally unknown. This is incongruous, since in the West at least something is known about Japanese anarchism and, for example, both Kōtoku Shūsui (1871-1911) and Ōsugi Sakae (1885-1923) have had (albeit unsympathetic) biographies written on them by American scholars. ${ }^{4}$ In Chapter 2 I explain Kōtoku's and Ōsugi's contributions to anarchism in Japan and it is certainly far from my purpose in this book to belittle either of them. Both are towering personalities in the history of Japanese anarchism. Yet it is also fair to say that neither can be considered to have made a significant, 
original contribution to anarchist theory. On the international level they are secondary figures, since the roles they fulfilled were mainly to introduce and popularise Western theories of anarchism in Japan. By way of contrast, fate has not been kind to a gifted and original thinker like Hatta. Language has acted as a barrier to an appreciation in the West of his stature as a theoretician, while in Japan the prevalence of bolshevism within the relevant scholarly circles has caused him to be ignored. Hopefully, the publication of this book, which is the first full-length study of Hatta Shūzō and pure anarchism to appear in any language, will belatedly bring to Hatta and his comrades a little of the recognition they richly deserve.

At any rate, to return to my first two reasons for writing this book, the reader can be assured that the chapters which follow will focus on a refreshingly rebellious breed of Japanese, one of whom was Hatta, and on theories which challenge every assumption on which the capitalist state in Japan (and elsewhere, for that matter) currently rests. Those disinclined to gawp in open-mouthed admiration at the soulless consumerism of modern Japan should read on. The pure anarchists make a welcome change from the human automata featured in the ubiquitous manuals on Japanese management techniques. Likewise, their ideas stand in complete contrast to the unquestioning acceptance of hierarchy and profit which, if the same sources were to be believed, is supposed to be a genetically imprinted characteristic of the Japanese. Happily, what the pure anarchists demonstrate is that there is nothing about being Japanese which prevents men and women from recognising the shortcomings of capitalism or which inoculates them against the vision of an alternative system of free, communist social relations. 
xix

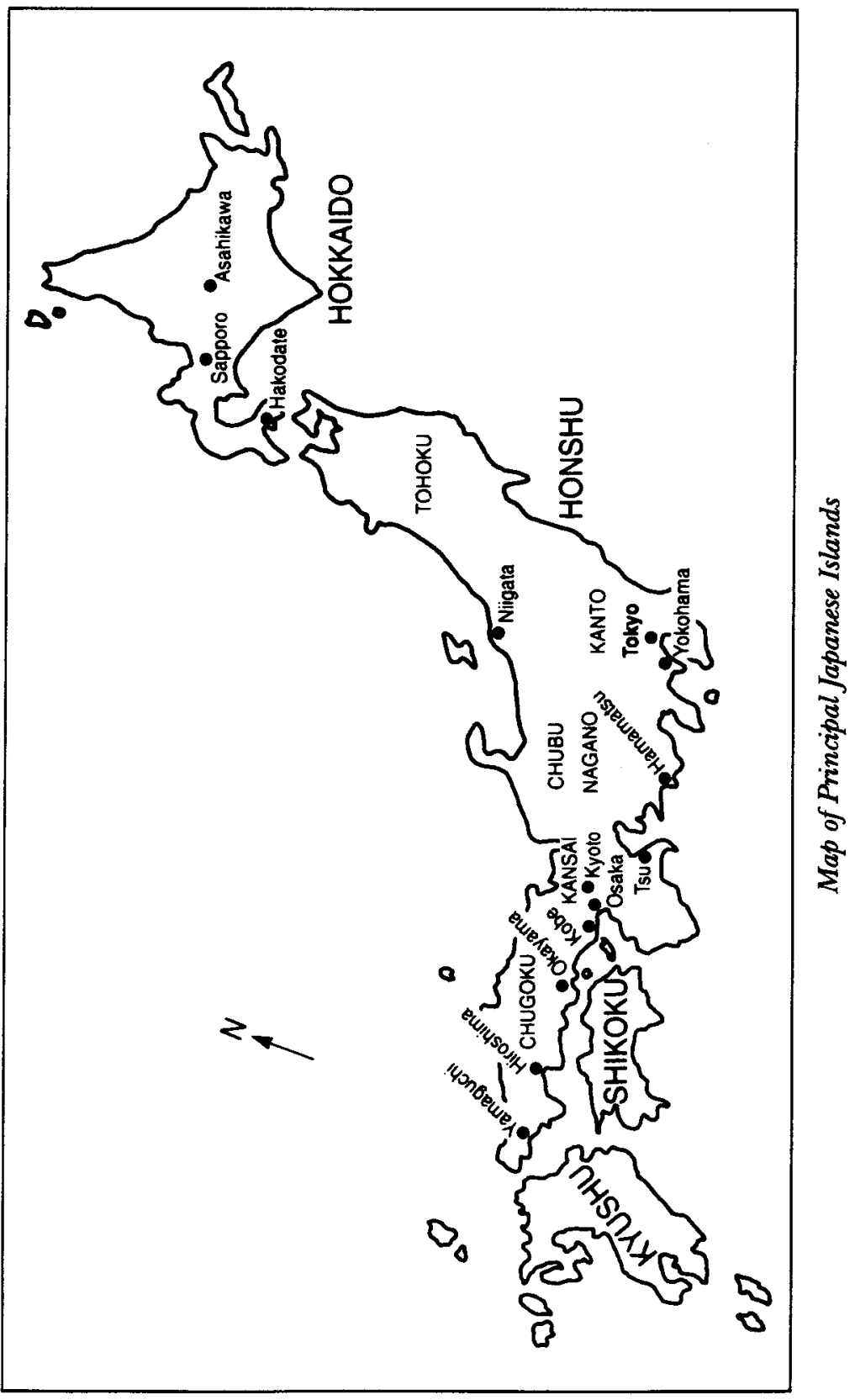

